\title{
КРИМІНОЛОГІЧНИЙ АНАЛІЗ РІВНЯ, ДИНАМІКИ ТА СТРУКТУРИ ЗАОЧИНІВ ПРОТИ АВТОРИТЕТУ ОРГАНІВ ДЕРЖАВНОЇ ВЛАДИ, ОРГАНІВ МІСЦЕВОГО САМОВРЯДУВАННЯ ТА ОБ’ЕДНАНЬ ГРОМАДЯН
}

\begin{abstract}
ІГНАТОВ Олександр Миколайович - кандидат юридичних наук, старший науковий співробітник, завідувач кафедри кримінально-правових дисциплін Євпаторійського факультету Харківського національного університету внутрішніх справ

ОРАОВ Юрій Володимирович - кандидат юридичних наук, доцент кафедри кримінального права та кримінології факультету підготовки фахівців для підрозділів слідства Харківського національного університету внутрішніх справ
\end{abstract}

УДК 343.24

Статья посвящена проблеме воспроизводства в Украине въгсокого уровня преступлений против авторитета органов государственной власти, органов местного самоуправления и объединений граждан. Сделан въгвод о нестабильности показателей динамики исследуемой группь преступлений, выссоком уровне их латентности, существенной связи с рецидивной преступностью. В структуре исследуемъхх преступлений вылвлено превалирование преступлений средней и небольшой тяжести, предусмотренных ст.ст. 342, 345, 357 и 358 УК Украинъл. Делается въивод о значительной зависимости их состояния от организачионно-управленческих ббакторов, в частности в деятельности ОВД.

Ключові слова: злочинність, рівень, динаміка, структура, латентність, ббактори.

Формування правової, соціальної, демократичної української держави вимагає постановки перед всім суспільством нових рубежів в своїй організації. Системні трансформації сфери державного управління в загальносоціальному руслі мають обов'язково враховувати й кримінологічну складову, як одну з пріоритетних. Визнання останнього зумовлює необхідність комплексного реформування апарату державного адміністрування на засадах поєднання правової, економічної, ідеологічної та кримінологічної політики, а також виведення правоохоронної системи на якісно інший рівень функціонування, який передбачає інституційну імплементованість в структури громадянського суспільства на базі сервісної моделі. В свою чергу в контексті означеного вектору переформатування системи соціального управління, а також враховуючи ступінь глибини та розгалуженості детермінаційного комплексу сучасної злочинності в Україні слід акцентувати увагу на винятковій важливості зміцнення авторитету органів державної влади, органів місцевого самоврядування та об'єднань громадян, в тому числі й шляхом зниження суспільної небезпечності відповідних посягань на цю сферу суспільних відносин. Останнє передбачає, перш за все, формування інформаційної діагностичної моделі 3 відповідних кримінологічно значущих показників та їх відповідної наукової інтерпретації, що і є метою цієї статті.

Окремі аспекти запобігання різним злочинам проти авторитету органів державної влади, місцевого самоврядування та об'єднань громадян досліджувались у працях Ю. В. Багалая, В. П. Беленока, А. В. Бойка, І. М. Зелялова, А. Ф. Імамутдинова, В. І. Осадчого, Д. В. Попова, М. М. Сенька, А. М. Удода, О. В. Юношева та інших вчених. Визнаючи суттєвий внесок означених науковців у розробку даної проблематики, слід все ж визнати певний дефіцит комплексних кримінологічних досліджень: у роботах перелічених авторів в основному порушувались питання вдосконалення кримінально-правових засобів протидії окремим видам злочинів відповідної категорії, або ж їх розрізнені кримінологічні характеристики $[1 ; 2 ; 3 ; 4$ та ін.]. 
Проведений нами аналіз кількісних показників злочинів, передбачених Розділом XV КК України виявив неоднозначні тенденції щодо динаміки їх відтворення. Так, слід перш за все акцентувати увагу на збереженні досить високого їх рівня та нестабільній динаміці. За період з 2002 по 2011 роки в Україні було зареєстровано 166335 злочинів проти авторитету органів державної влади, органів місцевого самоврядування та об'єднань громадян. Найбільш суттєвий приріст цих злочинів було зафіксовано в період з 2007 по 2009 рр. (див. діаграму 1). у серпні 2003, у лютому 2005, грудні 2006, жовтні 2007, січні 2010, листопаді 2011 року. Абстрагуючись від конкретних персоналій та зіставляючи кадрові трансформації керівного складу МВС з показниками рівня зареєстрованих злочинів проти авторитету органів державної влади, органів місцевого самоврядування та об'єднань громадян, доходимо висновку, що суттєве зниження останнього припадає саме на управлінські каденції «жовтень 2007 - січень 2010» та «січень 2010 - листопад 2011». Результати проведеного нами опитування 75 працівників ОВС зі стажем роботи 5 і більше років щодо

Діаграма 1.

Рівень та динаміка злочинів проти авторитету органів державної влади, органів місцевого самоврядування та об’єднань громадян в Україні (2002-2011рр.)

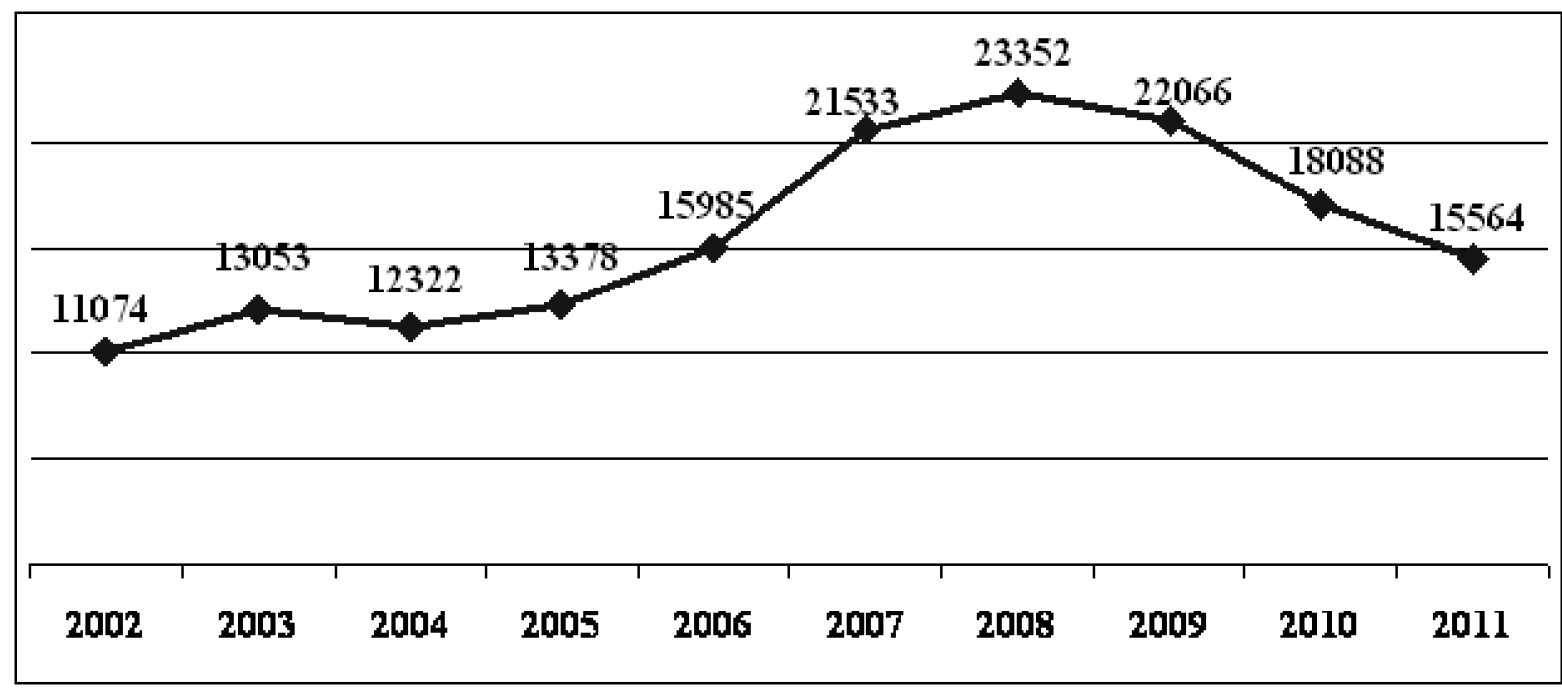

При цьому у вказаний період рівень злочинів максимально збільшився не лише щодо базисного 2002 року, а й щодо попередніх років. Найбільше значення аналізованого показника зафіксоване у 2008 році, після чого намітилась тенденція до зниження. На нашу думку, така картина може бути пояснена не стільки змінами у змісті детермінант відповідної групи злочинів, скільки організаційно-управлінськими факторами, що впливають на їх виявлення та реєстрацію. Так, зокрема, практично всі найбільш суттєві коливання у зареєстрованому рівні досліджуваної групи злочинів співпадають у часі зі змінами у найвищих щаблях керівництва МВС України, а саме: відповідні ротації на посту міністра МВС відбувалися організаційно-управлінських умов проходження служби у зазначені періоди, а також контент-аналіз матеріалів 3МI, засвідчили суттєвий вплив у вказані періоди політичних факторів на роботу системи МВС в цілому, а також недостатньо науково обгрунтовану кадрову політики щодо істотного скорочення чисельності персоналу ОВС. Останне, зокрема, навіть на рівні статистичних закономірностей суттєво вплинуло на досліджувані кримінологічно значущі показники.

Більш детальне уявлення про показники динаміки злочинів проти авторитету органів державної влади, органів місцевого самоврядування та об'єднань громадян вдається отримати при відповідних розрахунках, результати яких зведені до таблиці 1. 
Таблиця 1.

Розрахунок показників динаміки злочинів проти авторитету органів державної влади, органів місцевого самоврядування та об’єднань громадян в Україні (2002-2011рр.)

\begin{tabular}{|c|c|c|c|c|c|c|c|c|c|c|}
\hline \multirow[t]{2}{*}{ Показники злочинності } & \multicolumn{10}{|c|}{ Роки } \\
\hline & 2002 & 2003 & 2004 & 2005 & 2006 & 2007 & 2008 & 2009 & 2010 & 2011 \\
\hline $\begin{array}{l}\text { Загальна кількість заре- } \\
\text { єстрованих злочинів } 3\end{array}$ & 11074 & 13053 & 12322 & 13378 & 15985 & 21533 & 23352 & 22066 & 18088 & 15564 \\
\hline $\begin{array}{l}\text { Абсолютний приріст від- } \\
\text { носно } 2002 \text { року }\end{array}$ & - & 1979 & 1248 & 2304 & 4911 & 10459 & 12278 & 10992 & 7014 & 4490 \\
\hline $\begin{array}{l}\text { Абсолютний приріст } \\
\text { відносно попереднього } \\
\text { року }\end{array}$ & - & 1979 & -731 & 1056 & 2607 & 5548 & 1819 & -1286 & -3978 & -2524 \\
\hline $\begin{array}{l}\text { Темп зростання віднос- } \\
\text { но } 2002 \text { року }\end{array}$ & - & 1,18 & 1,1 & 1,21 & 1,44 & 1,94 & 2,11 & 1,99 & 1,63 & 1,41 \\
\hline $\begin{array}{l}\text { Темп зростання віднос- } \\
\text { но попереднього року }\end{array}$ & - & 1,18 & 0,94 & 1,09 & 1,19 & 1,35 & 1,09 & 0,94 & 0,82 & 0,86 \\
\hline $\begin{array}{l}\text { Темп приросту відносно } \\
2002 \text { року (\%) }\end{array}$ & - & 17,9 & 11,3 & 20,8 & 44,3 & 94,4 & 110,9 & 99,3 & 63,3 & 40,5 \\
\hline $\begin{array}{l}\text { Темп приросту відносно } \\
\text { попереднього року (\%) }\end{array}$ & - & 17,9 & $-5,6$ & 8,6 & 19,5 & 34,7 & 8,4 & $-5,5$ & -18 & -14 \\
\hline Середній рівень ряду & \multicolumn{10}{|c|}{16642} \\
\hline $\begin{array}{l}\text { Середній абсолютний } \\
\text { приріст }\end{array}$ & \multicolumn{10}{|c|}{498,8} \\
\hline $\begin{array}{l}\text { Середній темп зростан- } \\
\text { ня }\end{array}$ & \multicolumn{10}{|c|}{1,088} \\
\hline $\begin{array}{l}\text { Середній темп прирос- } \\
\text { ту (\%) }\end{array}$ & \multicolumn{10}{|c|}{8,8} \\
\hline
\end{tabular}

Таким чином, як можна бачити, динаміку досліджуваної групи злочинів можливо виразити через синусоїдну функціональну тенденцію із зростанням абсолютних показників в середньому в 498 злочинів за рік. Часовий проміжок коливання за критерієм стабільного темпу зростання (від позитивного до негативного значення) - приблизно 3,5 роки , повний цикл (від позитивного до позитивного значення до умовно ${ }^{1}$ аналогічного темпу приросту) - приблизно 7 років.

Також слід звернути увагу й на ту обставину, що зазначені показники динаміки не співпадають із відповідними показниками загальної злочинності в Україні, як 3 2002 до 2008 р. демонстрували тенденцію до зниження (за виключенням 2003 р.), а 3 2009 р. - зростання, що було зумовлено на-

\footnotetext{
1 Умовність оцінки темпів приросту означає визнання того, що аналізована система коливання показників є, по-перше, нелінійною та, по-друге, вимушеною, тобто такою, що залежить від значної кількості зовнішніх факторів.
}

ростаючими кризовими явищами у кредитно-фінансовій системі країни та, відповідно, соціальній сфері, непродуманими кроками у реформуванні системи ОВС та скорочення кадрів, зростанням рівня рецидивної злочинності, що можливо, на нашу думку, пояснити поступовим сплином строків відбування покарань значної кількості осіб, засуджених у пікові для криміногенної ситуації в нашій країні роки - кінець 90-х років минулого століття тощо. В цілому до 2008 р. не фіксувалося різких змін детермінаційного комплексу злочинності, практично всі кримінологічно значущі показники були на сталому рівні: соціально-економічні, культурно-психологічні, організаційно-управлінські, правові криміногенні фактори, параметри системи протидії злочинності. Разом $з$ тим, як випливає з викладених у таблиці 1 даних, з 2002 до 2008 р. відбувається зростання абсолютних приростів більш ніж у два рази, що, звичайно, викликає досить серйозне занепокоєння з огляду на якісну 
характеристику родового об'єкту розглядуваної групи злочинів. Натомість з 2008 р. всупереч загальним тенденціям змін криміногенної ситуації в країні (криміногенні фактори, стан системи протидії злочинності), динаміка злочинів проти авторитету органів державної влади, органів місцевого самоврядування та об'єднань громадян демонструє тенденцію до зниження.

Отже, аналіз ситуації, що склалася наочно засвідчує суттєву залежність відомостей

\section{Діаграма 2}

Структура злочинів проти авторитету органів державної влади, органів місцевого самоврядування та об'єднань громадян в

Україні за ступенем їх тяжкості (у \%)

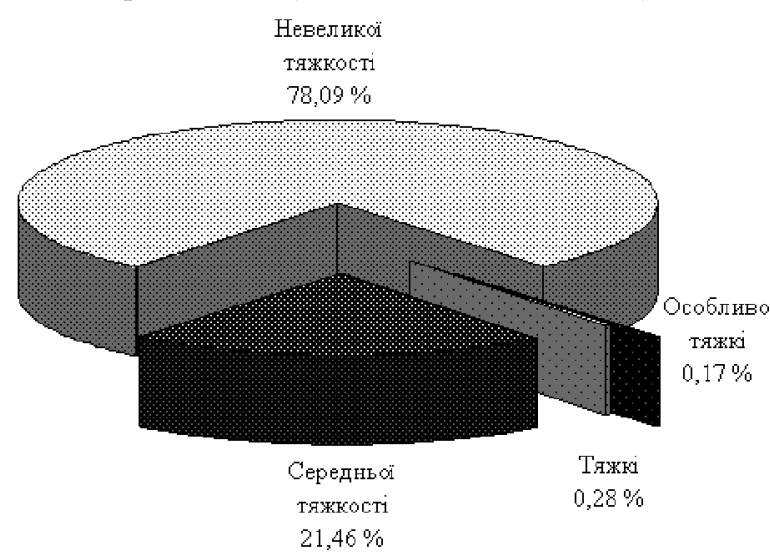

офіційної державної статистичної звітності від організаційно-управлінських факторів. Іншими словами наявна картина є викривленою та не відповідає реальній ситуації. Однак, з яких причин відбулося зазначене викривлення? Відповідь на це питання перебуває в площині більш глибинного дослідження наявних статистичних зведень. Зокрема, мова йде про аналіз структури відповідної групи злочинів, виявлення ії змін в динаміці та фіксації тих іiї складових, які чинять найбільш суттєвий вплив на показники загального рівня досліджуваних злочинів.

Перш за все варто звернути увагу на структуру злочинів проти авторитету органів державної влади, органів місцевого самоврядування та об'єднань громадян за критерієм їх тяжкості. Так, протягом аналізованого десятирічного періоду було вчинено 260 особливо тяжких, 447 тяжких злочинів, 35745 злочинів середньої тяжкості та 129883 злочинів невеликої тяжкості (див. діаграму 2).

Як можна бачити, основна конфігурація стану досліджуваної групи злочинів визначається за рахунок злочинів невеликої тяжкості, що дає підстави охарактеризувати цю групу як злочини переважно невеликої тяжкості. При цьому кількість особливо тяжких та тяжких злочинів протягом останніх деся-

Діаграма 3

Динаміка злочинів проти авторитету органів державної влади, органів місцевого самоврядування та об’єднань громадян в Україні за ступенем їх тяжкості

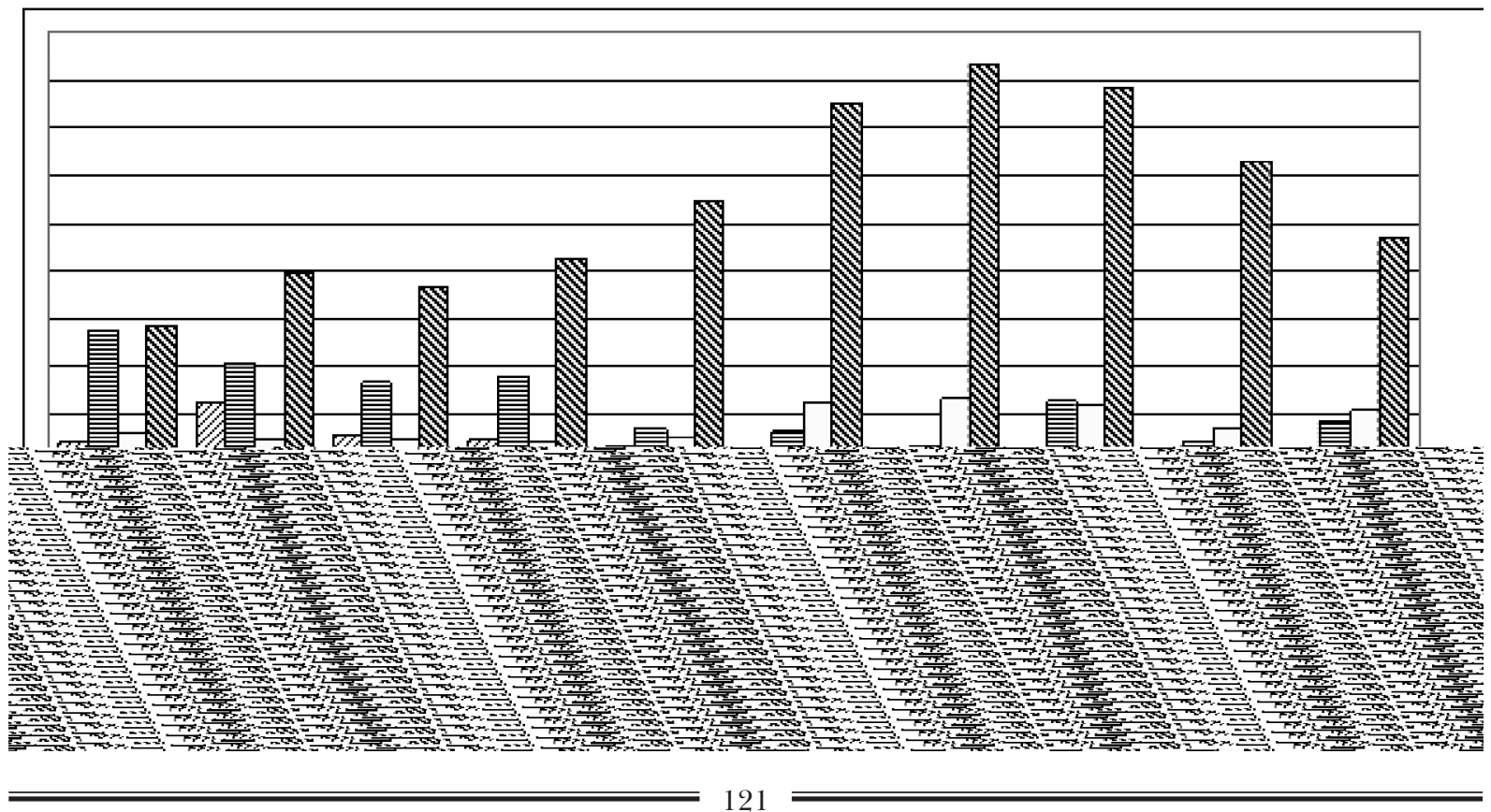


ти років залишалась приблизно сталою та коливалась в середньому в межах 21-25 та 32-40 злочинів за рік відповідно.

Натомість кількість злочинів середньої та особливо невеликої тяжкості досить суттево коливалась протягом аналізованого періоду часу та фактично визначала особливості змін у динаміці злочинів всієї групи. Так, незважаючи на тенденції до зростання кількості особливо тяжких, тяжких та злочинів середньої тяжкості, що сформувалася у 2010 р., злочини невеликої тяжкості демонстрували зниження рівня, що в цілому й зумовило загальну негативну динаміку.

Аналогічна ситуація, але відмінна за значенням спостерігалась і у період з 2003 по 2006 р., коли кількість особливо тяжких, тяжких злочинів та злочинів середньої тяжкості скорочувалась, а злочинів невеликої тяжкості суттєво збільшувалась, що також визначила тренд цього періоду з до загального зростання (див. діаграму 3).

Викладені обставини підштовхують до висновку, що зниження рівня злочинів проти авторитету органів державної влади, органів місцевого самоврядування та об'єднань громадян, яке фіксується, починаючи з 2009 р., обумовлене лібералізацією політики протидії злочинам невеликої тяжкості. Більш детально виявити напрямок послаблення інтенсивності кримінальнопревентивної діяльності дозволяе аналіз кримінально-правової структури зазначеної групи злочинів, зокрема за критерієм безпосереднього об’єкту посягання (див. діаграму 4).

\section{Діаграма 4}

Кримінально-правова структура злочинів проти авторитету органів державної влади, органів місцевого самоврядування та об'єднань громадян в Україні

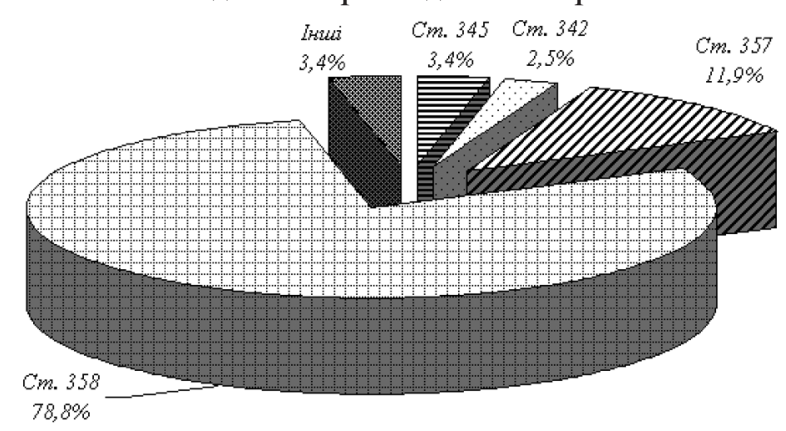

Аналіз кримінально-правової структури аналізованих видів злочинів засвідчуе залежність відповідних трендів, відображених на діаграмах 1 та 3, в основному від показників рівня таких злочинів невеликої тяжкості, як: а) підроблення документів, печаток, штампів та бланків, збут чи використання підроблених документів, печаток, штампів (ст. 358 КК); б) викрадення, привласнення документів, печаток, штамів, заволодіння ними шляхом шахрайства чи зловживання службовим становищем або їх пошкодження (ст. 357 КК; в) погроза або насильство щодо працівника правоохоронного органу (ст. 345 КК); г) опір представнику влад, працівникові правоохоронного органу, державному виконавцю, члену громадського формування з охорони громадського порядку i державного кордону або військовослужбовцеві (ст. 342 КК).

Отже, визначальними для динаміки досліджуваної групи злочинів в цілому виявляються злочини у сфері документообігу, зокрема ті, відповідальність за які передбачена ст. ст. 357 та 358 КК України. В свою чергу суттєве збільшення рівня цих злочинів, що фіксувалося в період з 2002 по 2008 рр. включно, на нашу думку, можна пояснити специфікою юридичного складу злочину, яка полягає у цільовій спрямованості злочинних дій. Як засвідчує судово-слідча практика, значна кількість корисливих злочинів вчиняється 3 використанням викрадених, підроблених документів, печаток або штампів, а саме: шахрайство, привласнення або розтрата майна, яке знаходиться у віданні особи, заподіяння майнової шкоди шляхом обману або зловживання довірою, ухилення від сплати податків, інших обов'язкових платежів, контрабанда тощо. А, як відомо, в означений період часу в країні відбувалося зростання саме цих злочинів, чим до певної міри пояснюється і суттєве зростання рівня злочинів, передбачених ст.ст. 357 та 358 КК України.

Однак, не дивлячись на збереження негативної тенденції до приросту корисливих злочинів (як загальнокримінальної, так і економічної спрямованості) протягом 2008-2010 років, у динаміці викрадення, підроблення документів, печаток, штампів 
Ігнатов О.М., Орлов Ю.В. - Кримінологічний аналіз рівня, динаміки...

\begin{tabular}{|c|c|c|c|c|c|c|c|c|c|c|c|c|c|c|}
\hline 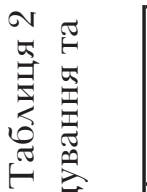 & $\begin{array}{l}\overrightarrow{7} \\
\text { จे } \\
\end{array}$ & 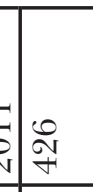 & \begin{tabular}{|l}
0 \\
D \\
2 \\
\end{tabular} & $\infty$ & $\stackrel{\mathscr{V}}{\simeq}$ & 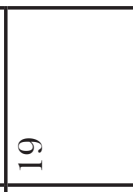 & $\begin{array}{l}\hat{O} \\
\stackrel{2}{N} \\
\end{array}$ & $H$ & $\stackrel{\infty}{=}$ & - & $\begin{array}{l}0 \\
8 \\
0 \\
-\end{array}$ & 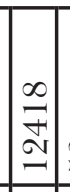 & is & $\begin{array}{l}0 \\
\sim \\
\end{array}$ \\
\hline 离 & \begin{tabular}{l}
0 \\
$\vdots$ \\
\multirow{2}{*}{} \\
\end{tabular} & 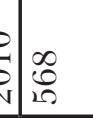 & \begin{tabular}{|l}
0 \\
0 \\
0 \\
0
\end{tabular} & $=$ & $=$ & $a \mathfrak{a}$ & $\begin{array}{l}\text { I } \\
\text { V }\end{array}$ & 0 & 워 & $尺$ & $\begin{array}{l}10 \\
10 \\
1 \\
\end{array}$ & $\begin{array}{l}\text { 辛 } \\
\text { t } \\
\end{array}$ & 品 & $\stackrel{\sim}{\sim}$ \\
\hline$\frac{\vec{U}}{\vec{E}}$ & $\begin{array}{l}0 \\
\dot{0} \\
\stackrel{a}{N}\end{array}$ & $\begin{array}{l}\infty \\
\infty \\
0 \\
0 \\
10\end{array}$ & $\mid \begin{array}{l}\hat{N} \\
\hat{N}\end{array}$ & 0 & $\stackrel{\vartheta}{=}$ & के & $\begin{array}{l}\tilde{N} \\
\text { N } \\
\text { wn }\end{array}$ & $\exists$ & $\stackrel{\infty}{-}$ & $\infty$ & $\begin{array}{l}\frac{10}{20} \\
\stackrel{a}{N}\end{array}$ & $\begin{array}{l}\infty \\
\infty \\
\infty \\
1 \\
-1 \\
\end{array}$ & $\stackrel{2}{2}$ & $\mid \begin{array}{l}\infty \\
\infty\end{array}$ \\
\hline $\begin{array}{l}0 \\
\hat{E}\end{array}$ & $\left|\begin{array}{l}\infty \\
0 \\
0 \\
\sim\end{array}\right|$ & 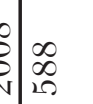 & $\frac{\Omega}{1}$ & $\exists$ & $\stackrel{0}{=}$ & 우 & $\begin{array}{l}\infty \\
\infty \\
\sim \\
\sim\end{array}$ & 10 & $\stackrel{N}{N}$ & $\stackrel{1}{\circ}$ & $\vec{\sigma}$ & 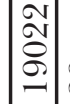 & $\stackrel{2}{N}$ & $\left|\begin{array}{l}\infty \\
\infty\end{array}\right|$ \\
\hline 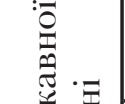 & 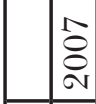 & 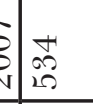 & $\begin{array}{l}0 \\
\mathbb{N} \\
1\end{array}$ & $\stackrel{\infty}{-}$ & $\stackrel{0}{=}$ & 10 & 点 & $\Xi$ & $\begin{array}{l}\infty \\
\stackrel{0}{0} \\
\text { N }\end{array}$ & $\infty$ & $\begin{array}{l}\text { Oे } \\
\text { o } \\
\text { v }\end{array}$ & $\begin{array}{l}0 \\
0 \\
0 \\
0 \\
-1\end{array}$ & ¿ & $\begin{array}{l}12 \\
0 \mathrm{~N}\end{array}$ \\
\hline 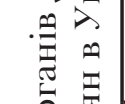 & $\begin{array}{l}0 \\
0 \\
0 \\
\sim \\
\end{array}$ & 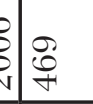 & 点 & \pm & 0 & $\begin{array}{l}\infty \\
10 \\
\end{array}$ & 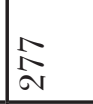 & 10 & 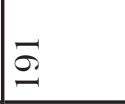 & \&) & $\frac{a}{\vec{a}}$ & $\begin{array}{l}5 \\
\Xi \\
\Xi\end{array}$ & $\underset{+}{\stackrel{P}{0}}$ & $\begin{array}{c}\mathcal{Y} \\
\forall\end{array}$ \\
\hline 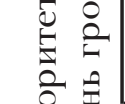 & \begin{tabular}{l}
20 \\
0 \\
\multirow{2}{*}{}
\end{tabular} & 辛 & 18 & $\infty$ & 12 & 0 & $\begin{array}{l}\infty \\
\infty \\
\sim\end{array}$ & 19 & $\begin{array}{l}0 \\
\cdots \\
\sim\end{array}$ & $\therefore$ & $\begin{array}{l}\hat{a} \\
\text { aे } \\
\text { a }\end{array}$ & $\left|\begin{array}{l}\infty \\
0 \\
20 \\
0\end{array}\right|$ & S) & $\underset{y}{\mathscr{y}}$ \\
\hline $\begin{array}{l}5 \\
0 \\
0 \\
0 \\
0\end{array}$ & 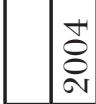 & 家 & $\vec{F}$ & 0 & 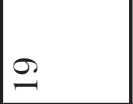 & $\mid \infty$ & 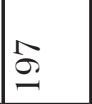 & $\vec{\sim}$ & $\underset{v}{*}$ & 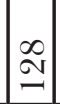 & 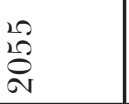 & $\left(\begin{array}{l}1 \\
0 \\
\infty\end{array}\right.$ & $\underset{F}{H}$ & $\mid \begin{array}{c}0 \\
\infty\end{array}$ \\
\hline & $\begin{array}{l}0 \\
0 \\
0 \\
\sim\end{array}$ & $\begin{array}{ll}\infty \\
\infty\end{array}$ & 尽 & 12 & $\mathscr{N}$ & $\begin{array}{l}\tilde{2} \\
\infty\end{array}$ & $\mid$\begin{tabular}{l}
10 \\
\multirow{2}{2}{}
\end{tabular} & 10 & $\begin{array}{l}\text { on } \\
\text { on }\end{array}$ & $\begin{array}{c}0 \\
1 \\
-1\end{array}$ & $\begin{array}{l}\stackrel{v}{ } \\
\text { Sे } \\
\text { N }\end{array}$ & $\left|\begin{array}{c}20 \\
\sqrt{2} \\
\infty\end{array}\right|$ & 8 & is \\
\hline$\sum_{0}^{x}$ & 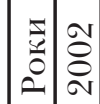 & 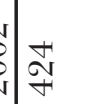 & $\stackrel{\mathscr{Q}}{\mathscr{Y}}$ & $\mid \mathcal{E}$ & $\cong$ & $\infty$ & $\stackrel{\vec{D}}{\mathscr{N}}$ & 7 & $a$ & 웜 & $\begin{array}{l}0 \\
\text { a } \\
\text {. }\end{array}$ & $\left|\begin{array}{l}1 \\
\hat{N} \\
\mathbb{N} \\
\hat{N}\end{array}\right|$ & $+\infty$ & 12 \\
\hline 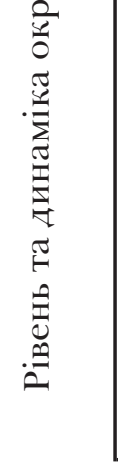 & 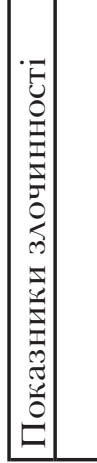 & 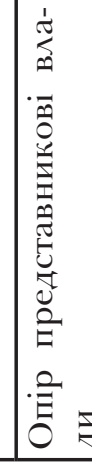 & 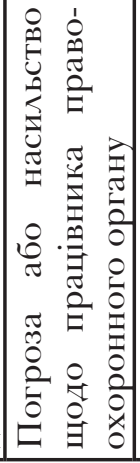 & 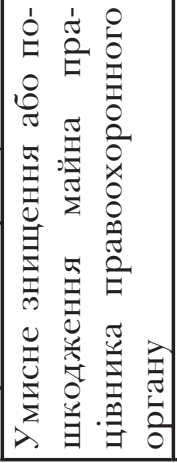 & 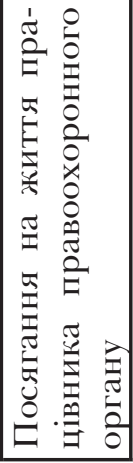 & 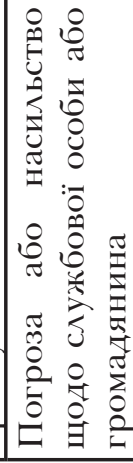 & 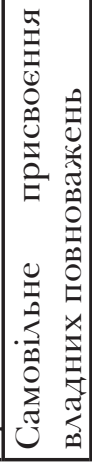 & 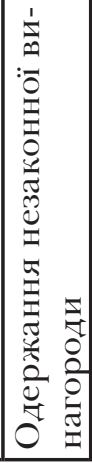 & 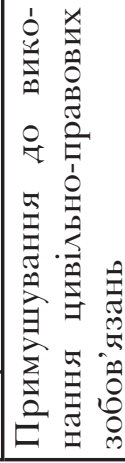 & 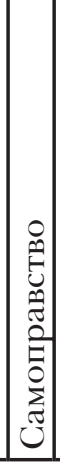 & 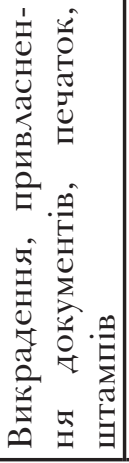 & 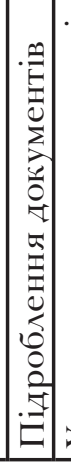 & 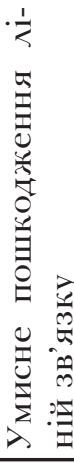 & $\Xi$ \\
\hline
\end{tabular}




\section{Кримінальне право, кримінальний процес та криміналістика}

відобразились зворотні тенденції, тобто фіксувалося суттєве зниження рівня, яке відмічалося також і щодо більшості злочинів досліджуваної групи, за винятком також посягання на життя працівника правоохоронного органу, самовільного присвоєння владних повноважень, умисного пошкодження ліній зв'язку та деяких інших. Разом $з$ тим, негативні тенденції динаміки (тобто щодо зниження іії показників) загальної та економічної корисливої злочинності за 2011 рік вже відповідають аналогічним показникам злочинів проти авторитету органів державної влади, органів місцевого самоврядування та об'єднань громадян.

Викладене підтверджує справедливість висновку про суттєве залежності між статистичним відображенням показників злочинів досліджуваної групи та організаційно-управлінськими факторами - послабленням у роботі правоохоронних органів протягом 2008-2010 років, зокрема у напрямку виявлення та припинення злочинів проти авторитету органів державної влади, органів місцевого самоврядування та об'єднань громадян, що відносяться до категорії невеликої тяжкості. Об'єктивно, тобто в силу залежності конститутивних для структури аналізованих злочинів видів кримінальної поведінки, передбаченої ст.ст. 357 та 358 КК України, від злочинів загальнокримінальної та економічної корисливої спрямованості, зниження показників їх динаміки мало 6 бути зафіксовано лише у 2011 році. Відтак, враховуючи законодавчі вимоги щодо підслідності кримінальних справ про злочини означених видів, $є$ підстави для висновку про наявність відповідних недоліків в антикримінальній діяльності протягом 2008-2010 років саме з боку ОВС. При цьому вести мову про збільшення ефективності запобіжної їх діяльності в означеному напрямку також не доводиться через відсутність відповідних ефектів у показниках корисливих злочинів, про які йшлося вище.

Таким чином, приймаючи до уваги викладені розрахунки, слід, на нашу думку, вказати і на суттєвий рівень латентності злочинів проти авторитету органів державної влади, органів місцевого самоврядування та об'єднань громадян, який обумовлюєть- ся нестабільністю превентивної діяльності правоохоронних органів та високою їх здатністю до криміногенної самодетермінації, на що вказується й у низі досліджень «міліцейської злочинності», зокрема у працях О. А. Мартиненка, О. С. Новакова, С. А. Шалгунової. Остання обставина, зокрема, актуалізує необхідність аналізу статистичних відомостей про вчинення злочинів досліджуваної групи особами, які мали судимість.

В цілому у структурі всіх злочинів, передбачених Розділом XV КК України, рецидивна злочинність складає біля $8 \%$. Натомість щодо злочинів, передбачених ст. 358 КК України, цей показник становить $9 \%$, а передбачених ст. 357 КК України - 17,5\%, тобто практично у два рази вищий. Ці дані виводять на розуміння значної спільної поверхні дотику детермінаціних площин рецидивної злочинності та досліджуваних видів злочинів. I успіх у справі протидії останнім суттєво залежить від ефективного утримання приросту саме рецидивних злочинів. Разом з тим, проблема рецидиву злочинів (детермінація, характеристика особистості злочинця тощо), передбачених ст.ст. 357, 358 КК України на сьогоднішній день у вітчизняній кримінології не розроблена в достатній мірі, потребує прискіпливої наукової уваги на монографічному рівні дослідження. Результати останнього в подальшому мають сформувати додаткові елементи наукового забезпечення концепції і практики протидії злочинам проти авторитету органів державної влади, органів місцевого самоврядування та об'єднань громадян.

Отже, підбиваючи підсумки, слід акцентувати увагу на високому рівні досліджуваних злочинів. Разом з тим, їх динаміка може бути виражена синусоїдною функціональною залежністю: в цілому відображає тенденції до зростання із коливаннями, що мають суттєву залежність від організаційноуправлінських факторів.

Злочини проти авторитету органів державної влади, органів місцевого самоврядування та об'єднань громадян мають неоднорідну структуру, в якій превалюють злочини, передбачені ст.ст. 342, 345, 357 та 358 КК України, переважно без кваліфікуючих ознак та відносяться до категорії злочинів невели- 
Ігнатов О.М., Орлов Ю.В. - Кримінологічний аналіз рівня, динаміки...

\section{АНОТАЦІЯ}

Стаття присвячена проблемі відтворення в Україні високого рівня злочинів проти авторитету органів державної влади, органів місцевого самоврядування та об'єднань громадян. Зроблено висновок про нестабільність показників динаміки досліджуваної групи злочинів, високий рівень їх латентності, суттєвий зв'язок з рецидивною злочинністю. У структурі досліджуваних злочинів виявлено превалювання злочинів середньої та невеликої тяжкості, передбачених ст.cm. 342, 345, 357 ma 358 КК України. Робиться висновок про значну залежність їх стану від організаиійно-управлінсъких бакторів, зокрема у діяльності ОВС.

кої чи середньої тяжкості. Поряд з цим, вони виявляють істотну залежність від показників корисливих злочинів загальнокримінальної та економічної спрямованості. Окремо звертає на себе увагу зв'язок досліджуваних злочинів із рецидивною злочинністю.

Також слід звернути увагу на розбіжностях показників досліджуваних злочинів із тенденціями відтворення загальної злочинності, що, на нашу думку, може бути пояснене, по-перше, значним рівнем латентності злочинів проти авторитету органів державної влади, органів місцевого самоврядування та об'єднань громадян та, по-друге, організаційно-управлінськими вадами у діяльності ОВС: структурно-функціональною залежністю діяльності системи в цілому в окремі періоди від політичних факторів, суттєвими прорахунками в кадровій політиці МВС щодо науково необгрунтованого скорочення персоналу тощо. Викладене спонукає до подальшого інтегративного наукового пошуку ефективних кримінально-превентивних заходів відповідної спрямованості на засадах деструктивного впливу на спільні групи криміногенних факторів щодо: а) злочинів проти авторитету органів державної влади, органів місцевого самоврядування та об'єднань громадян; б) рецидивної злочинності; в) 3лочинності працівників ОВС.

\section{Лiтература}

1. Баглай Ю. В. Правовая регламентация уголовно-правовой охраны сотрудников правоохранительных органов, осу-

\section{SUMMARY}

The article is dedicated to the problem of reproduction in Ukraine of high level of crimes against authority of public, organs of local selfgovernment and associations of citizens authorities. Drawn conclusion about instability of indexes of dynamics of the investigated group of crimes, high level of their latentness, substantial connection with recurrent criminality. Predominating of crimes of middle and small weight is educed in the structure of the investigated crimes, envisaged art. 342, 345, 357 and 358 Crime Code of Ukraine. Drawn conclusion about considerable dependence of their state on organizationally-administrative factors, in particular in activity of organs of internal affairs.

ществляющих деятельность по охране общественного порядка и обеспечению общественной безопасности / Ю.В.Баглай // Ученые записки: сборник научных трудов юридического факультета ОГУ. Проблемы реализации конституционных норм: от истории к современности. - Оренбург: ИПК ГОУ ОГУ, 2009. - Вып. 6. - С. 467-474.

2. Осадчий В. I. Кримінально-правовий захист правоохоронної діяльності. Монографія / В. І. Осадчий. - К.: Атіка, 2004. $-336 \mathrm{c}$.

3. Сенько М. М., Беленок В. П. Окремі питання кримінально-правового захисту правоохоронної діяльності за законодавством України та деяких зарубіжних держав / М. М. Сенько, В. П. Беленюк // Науковий вісник Аьвівського державного університету внутрішніх справ. Серія юридична: 36. наук. пр. - Аьвів: АьвДУВС. - Вип. 1. - 2007. - C. 148-157.

4. Удод А. М. Об'єкт погрози або насильства щодо працівника правоохоронного органу (ст. 345 КК України) / А. М. Удод // Вісник Кримінологічної асоціації України : матеріали Всеукраїнської наук.-практ. конференції, присвяченої 20-річчю заснування кафедри кримінального права та кримінології Харківського національного університету внутрішніх справ «Актуальні сучасні проблеми кримінального права та кримінології у світлі реформування кримінальної юстиції» (м. Харків, 12 травня 2012 року), T. 1. - Х.: Золота миля, 2012. - С. 299-301. 